\title{
EFFECT OF CONSORTIUM OF PLANT GROWTH PROMOTING AND COMPOST INHABITING BACTERIA ON PHYSICOCHEMICAL CHANGES AND DEFENSE RESPONSE OF MAIZE IN FUNGUS INFESTED SOIL
}

\author{
Naseem Akhtar ${ }^{1}$,, Muhammad Naveed ${ }^{1}$, Muhammad Zafar Iqbal' ${ }^{3}$, Muhammad Khalid ${ }^{1}$ and \\ Ejaz Ahmad Waraich ${ }^{2}$ \\ ${ }^{1}$ Institute of Soil and Environmental Sciences, University of Agriculture, Faisalabad, Pakistan; ${ }^{2}$ Department of \\ Agronomy, University of Agriculture, Faisalabad, Pakistan; ${ }^{3}$ Agricultural Biotechnology Research Institute, \\ AARI, Faisalabad, Pakistan. \\ "Corresponding author's e-mail: nasimsajjad235@gmail.com
}

\begin{abstract}
Biotic stress in the rhizospheric environment induces defense mechanism in plant via signaling between plant and nonpathogenic microbes. In order to evaluate the defense response of maize plant, in relation to beneficial bacteria, a jar experiment was conducted in diseased soil (infected with Fusarium oxysporum). Seed was inoculated with consortium of selected isolates of plant growth promoting rhizobacteria (PGPR, Mb4 (Bacillus spp.), Mb7 (Pseudomonas aeruginosa) and compost inhabiting bacteria (CIB, Cb4 (Serratia spp.) and Cb9 (Pseudomonas spp.). Inoculum was used as inducer of defense compounds in maize crop. Hoagland half strength solution was applied to meet the water and nutrient requirements of the plants. Treatments were arranged in completely randomized design under axenic condition and were repeated thrice. Results indicated that different combination of Mb4 (Bacillus spp.), Mb7 (Pseudomonas aeruginosa), Cb4 (Serratia spp.) and Cb9 (Pseudomonas spp.) showed 100 percent seed germination than un-inoculated control. Significantly higher root/shoot growth were observed in treatments, inoculated with consortium of selected isolates. Survival of maize plants in diseased environment is the result of physicochemical changes in plant. Proline contents were observed up to $4.97 \mu \mathrm{mol} \mathrm{g}^{-1}$ in bacterial inoculated treatment compared to un-inoculated control $\left(1.760 \mu \mathrm{molg}^{-1}\right)$. Consortium of above mentioned isolates helped to maintain the chlorophyll ' $a$ ' ' $b$ ' and higher relative water contents than control. Inoculation with different consortia of selected isolates reduced membrane permeability up to $54.18 \%$. The higher catalase activity was $4.5 \mathrm{mM} \mathrm{H}_{2} \mathrm{O}_{2} \min ^{-1} \mathrm{~g}^{-1}$, while ascorbate peroxidase activity was $0.57 \mu \mathrm{M} \mathrm{H}_{2} \mathrm{O}_{2} \min ^{-1} \mathrm{~g}^{-1}$ due to inoculation with bacterial consortia. It is therefore concluded that consortium inoculation of compatible bacterial isolates induced physicochemical changes in stressed plant, which help plant to withstand the biotic stress and promote growth.

Keywords: Antioxidants, disease suppression, Fusarium oxysporum, maize, soil pathogens.
\end{abstract}

\section{INTRODUCTION}

Soil borne pathogens are responsible for considerable yield losses in field crops. Different species of Fusarium i.e. F. culmorum and $F$. pseudograminearum were the combined causal organisms of seedling blight in many cereal crops (Charles et al., 2007).

Plants, facing biotic stress, strongly depend on internal resistance, to fight against pathogens. The internal resistance is activated due to the presence of pathogens in the rhizosphere. Plant immunity depends upon the resistance, developed due to defense responses (Boller and Felix, 2009). The plant- microbe interaction followed the signaling process by the production of reactive oxygen species and ion fluxes (Garcia-Brugger et al., 2006). In response to pathogen stress, salicylic acid and jasmonic acid were produced within hours, resulted in the regulation of defense genes (Browse, 2009; Vlot et al., 2009). Sometimes this reaction resulted in plant cell death in the particular infected region (hyper sensitive reaction) (Heath, 2000).

Soil-borne plant diseases can be controlled by composts (Noble and Coventry, 2005). Compost was useful against the Fusarium oxysporum f. sp. basilici while its ability to control diseases was due to microorganisms, inhabit in it (Reuveni et al., 2002). Composts vary in their physical, chemical and biological composition and accordingly control the soil borne pathogens (Termorshuizen et al., 2006). Compost inhabiting microbes showed varying capacity to suppress damping-off in cucumber, infected by Pythium ultimum (Carisse et al., 2003).

Some beneficial bacteria (PGPR) have the ability to enhance the defensive capacity of plants against soil borne pathogens (Pozo et al., 2002). They can inhibit the growth and activity of soil borne pathogen like fungi, oomycetes, bacteria and nematodes (Jos et al., 2009). These microbes indirectly defended the plant by inducing systemic resistance 
(Srivastava et al., 2010). The PGPR and CIB help plant to release elicitors in response to the presence of pathogens in the rhizosphere. Elicitation is used to induce the expression of genes responsible for the amalgamation of antimicrobial compounds (Sekar and Kandavel, 2010). They exert beneficial effects in terms of enhanced plant growth and decreased the sensitivity of plant to diseases (Compant et al., 2005). They suppressed the pathogens by producing antibiotic compounds (Deshwal et al., 2003) and compete by producing compounds such as siderophore (Arora et al., 2001). They contribute to osmotic adjustment by protecting the structure of macromolecule and membrane through the production of proline, sucrose, and other organic sugars (Prado et al., 2000). Proline is also play role in metabolism by providing nitrogen and acting as reducing agent (Meloni et al., 2001). Bacterial inoculation provides relief to the plant by enhancing chlorophyll contents and stomatal conductance under stress (Vivas et al., 2003). The aim of current study was to scrutinize compatible consortium of bacterial isolates, capable to induce defense compounds in stressed plant against Fusarium oxysporum. And to study the production of defense compounds and physiological changes for better understanding of biocontrol process.

\section{MATERIALS AND METHODS}

Collection and cross check of pathogen: The pathogen (Fusarium oxysporum) was collected from department of Plant Pathology, Ayub Agricultural Research Institute, Faisalabad. Pathogen was isolated by tissue segment method (Rangaswami, 1958) and identified by using colony morphology and microscopic features (Singh et al., 1991). Pathogenicity was proved by live plant and cut stem method (Barnett and Hunter (1975). For cross check of pathogen, the fresh broth culture of mycelial suspension was incubated for 6 days. Three weeks old seedlings of maize, grown in sterilized soil were inoculated with the mycelial suspension of the fungal isolates. Jars were observed for symptoms of the disease. The pathogen was re-isolated from the infected plants and compared with the initial isolates.

Isolation of PGPR: Maize rhizosphere samples were collected from different locations at the Ayub Agriculture Research Institute, Faisalabad, Pakistan. Isolation of PGPR was performed in the Soil Bacteriology Section, Agricultural Biotechnology Research Institute Faisalabad, using LuriaBertany (LB) agar medium (Luria and Burrous, 1995). The rhizosphere was dug out with intact root. The samples were placed in plastic bags and stored at $4{ }^{\circ} \mathrm{C}$ in refrigerator. Ten grams of rhizosphere soil placed in conical flask and $90 \mathrm{~mL}$ sterile distilled water was added. The flask was shaken for $10 \mathrm{~min}$ on a rotary shaker. One milliliter of suspension was added to a $10 \mathrm{~mL}$ tube and shaken for $2 \mathrm{~min}$. Serial dilutions with distilled water was performed up to $10^{-7}$ dilution. An aliquot $(0.1 \mathrm{~mL})$ of this suspension was spread on the plates of LB agar medium. Plates were incubated for 3 days at $28^{\circ} \mathrm{C}$. Bacterial colonies were streaked to other LB agar plates for purification and the plates incubated at $28^{\circ} \mathrm{C}$ for 3 days. Typical bacterial colonies were observed over the streaks and well isolated single colonies were picked up and re-streaked to fresh LB agar plates and incubated. The technique was perpetuated thrice and cultures were made single colony type. The isolated strains were coded and stored.

Isolation of compost inhabiting bacteria: Compost inhabiting bacteria were isolated using standard dilutionplating procedure as described by Pugliese et al. (2008). One gram of the compost samples was placed in $99 \mathrm{ml}$ of sterile distilled water in a conical flask, shaken vigorously on a vortex mixer for $10 \mathrm{~min}$ and then serially diluted with distilled water $\left(10^{-2}, 10^{-4}, 10^{-6}\right)$. An aliquot $(0.5 \mathrm{~mL})$ of these suspensions were spread on plates of Luria-Bertany (LB) agar medium. Inoculated plates were incubated at $28^{\circ} \mathrm{C}$ for $48 \mathrm{~h}$ and were sub-cultured on LB agar medium until pure cultures were established. The isolated strains were stored at $-40{ }^{\circ} \mathrm{C}$.

Consortium of PGPR and CIB: Selected isolates of PGPR (Mb4 (Bacillus spp.), Mb7 (Pseudomonas aeruginosa), and CIB (Cb4 (Serratia spp.) and Cb9 (Pseudomonas spp.) were used for consortium preparation and evaluation.

Jar experiment: Jar experiment was conducted in growth room of Agricultural Biotechnology Research Institute, Ayub Agricultural Research Institute (AARI), Faisalabad. Sterilized broth medium of LB (Tryptone $10 \mathrm{~g} \mathrm{~L}^{-1}$, Yeast extract $5 \mathrm{~g} \mathrm{~L}^{-1}$, Sodium chloride $5 \mathrm{~g} \mathrm{~L}^{-1}$ at $\mathrm{pH} 7.2$ at $37^{\circ} \mathrm{C}$ ) was inoculated with selected isolates $(\mathrm{Mb} 4, \mathrm{Mb} 7, \mathrm{Cb} 4$ and Cb9) and placed at $25 \pm 1^{\circ} \mathrm{C}$ in a shaking incubator. Consortium was prepared by combining these isolates in all possible combinations, using LB medium and tested their compatibility for disease control and growth promotion in maize crop. Jars were filled with sterilized silt at the rate of $500 \mathrm{~g} \mathrm{pot}^{-1}$ and treated with fungus. Before sowing, surface disinfected seed was inoculated by peat based inocula while control was un-inoculated but treated with slurry (peat, sugar and LB broth culture). All the treatments were placed according to completely randomized design and replicated thrice. Hoagland half strength solution (Hoagland, 1950) was applied to fulfill the requirements of water and nutrients when required. Data regarding germination percentage was recorded 48 hours after sowing by counting the germinated seed out of total seed sown. Disease incidence was recorded after fifteen days and calculated using following formula described by Vincent (1947),

$$
\text { Disease incidence }(\%)=\frac{\text { Number of infected plants }}{\text { total number of plants }} \times 100
$$

Fresh leaves $(2 \mathrm{~g})$ were sampled from each treatment, stored at $4^{\circ} \mathrm{C}$ and analyzed for physicochemical changes and defense related enzymes. 
Physicochemical changes: Relative water contents in fresh leaves were determined by following method given by Mayak et al. (2004). Briefly $0.5 \mathrm{~g}$ fresh leaves were sampled, weighed (FW) and placed in distilled water for full turgidity at $4^{\circ} \mathrm{C}$. After $48 \mathrm{hr}$, weight of fully turgid leaves was recorded. Then leaves were air dried followed by drying in an oven and noted the weight of oven dried leaves. Relative water contents were calculated via following formula (Whetherley, 1950).

$$
\text { Relative water contents }(\mathrm{RWC})=\frac{\mathrm{FW}-\mathrm{DW}}{\mathrm{FTW}-\mathrm{DW}} \times 100
$$

FW is the fresh weight, DW, dry weight and FTW is the fully turgid weight. Dry weight is the oven dry weight of sample for $24 \mathrm{~h}$, while the FTW was determined after it was held in $100 \%$ humidity at $4^{\circ} \mathrm{C}$ for two days.

Relative membrane permeability was determined by cutting uniform leaf discs with a sharp cork borer from several plants. Leaf discs were transferred to flasks having $20 \mathrm{~mL}$ of sterilized distilled water. The flasks shake for 10 s and measured the electrical conductivity (EC0) by conductivity meter. Kept the flasks over night at $4^{\circ} \mathrm{C}$ and examined the EC1. The flasks were then autoclaved at $121^{\circ} \mathrm{C}$ for $20 \mathrm{~min}$ to measure EC2. Relative membrane permeability was calculated by using the formula,

$$
\operatorname{RMP}(\%)=\frac{\mathrm{EC} 1-\mathrm{EC} 0}{\mathrm{EC} 2-\mathrm{EC} 0} \times 100
$$

Chlorophyll contents were measured by the method given by Arnon (1949). Fresh leaf sample of $0.5 \mathrm{~g}$ from each treatment was crushed in $80 \%$ acetone $(\mathrm{v} / \mathrm{v})$ and filtered. Samples were run to take absorbance in spectrophotometer at 663 and $645 \mathrm{~nm}$ for chlorophyll a and b, respectively, and calculated as

$\mathrm{Chl}$ ' $\mathrm{a}$ ' $(\mathrm{mg} / \mathrm{g}$ fresh weight $)=$

$$
[12.7(\text { O.D 663) }-2.69(\text { O.D 645) } \times \mathrm{V} / 1000 \times \mathrm{W}]
$$

$\mathrm{Chl}$ ' $\mathrm{b}$ ' (mg/g fresh weight $)=$

$$
\text { [22.9 (O.D 645) - } 4.68(\text { O.D 663) } \times \text { V/1000 } \times \text { W] }
$$

Where $\mathrm{V}$ is the volume of sample, $\mathrm{W}$ is weight of fresh tissue, O.D $480+0.114$ (O.D 663) - 0.638 (O.D 645)

Defense enzymes: Proline accumulation was determined using the method of Bates et al. (1973). One gram fresh leaf was homogenized with $3 \%$ sulfosalicylic acid and after $72 \mathrm{~h}$ the proline was released; the homogenate was centrifuged at $16000 \mathrm{rpm}$ for $20 \mathrm{~min}$. The supernatant was treated with glacial acetic acid and ninhydrin, kept at $96^{\circ} \mathrm{C}$ for 1 hour in water bath and cooled immediately by using ice bath to stop the reaction. The mixture was extracted with toluene and measured the absorbance at $520 \mathrm{~nm}$ by spectrophotometer. Standards were prepared with toluene having concentration of $0-5 \mathrm{ppm}$. Standard curve was used to determine the proline concentration and expressed as $\mu \mathrm{mol} \mathrm{g}^{-1}$.

Catalase is responsible for the decomposition of $\mathrm{H}_{2} \mathrm{O}_{2}$ expressed by decrease in absorbance at $240 \mathrm{~nm}$ spectrophotometerically. Leaf sample was extracted with potassium phosphate buffer $(50 \mathrm{mM})$. Required sample was prepared by taking $3 \mathrm{~mL}$ test mixture, $2 \mathrm{~mL}$ diluted leaf extract (diluted 200 times with $50 \mathrm{mM}$ potassium phosphate buffer) and $10 \mathrm{mM} \mathrm{H} \mathrm{H}_{2} \mathrm{O}_{2}$. The extinction co-efficient of $\mathrm{H}_{2} \mathrm{O}_{2}\left(40 \mathrm{mM}^{-1} \mathrm{~cm}^{-1}\right.$ at $\left.240 \mathrm{~nm}\right)$ was used to calculate the enzyme activity and expressed in millimoles of $\mathrm{H}_{2} \mathrm{O}_{2}$ per minute per gram fresh weight (Aebi, 1984).

Ascorbate peroxidase (APX) activity was determined by measuring the rate of decrease in absorbance of ascorbate at $290 \mathrm{~nm}$. APX activity was assessed by a modified method of Nakano and Asada, 1981. Leaf was grinded with potassium phosphate to get extract and $1 \mathrm{~mL}$ test mixture plus $50 \mathrm{mM}$ potassium phosphate buffer ( $\mathrm{pH} 7.0$ ), $0.5 \mathrm{mM} \mathrm{H}_{2} \mathrm{O}_{2}, 0.5 \mathrm{mM}$ ascorbate and $10 \mu \mathrm{L}$ of crude leaf extract. $\mathrm{H}_{2} \mathrm{O}_{2}$ was added in the end to start the reaction and decrease in absorbance was noted for $3 \mathrm{~min}$. The enzyme activity was calculated by using extinction co-efficient of $2.8 \mathrm{mM}^{-1} \mathrm{~cm}^{-1}$ for reduced ascorbate.

Total soluble sugar was determined by the procedure, described by Morris, 1948. Standard solution of glucose was prepared with concentration of 1-5 ppm. One $\mathrm{mL}$ of aqueous sample and four $\mathrm{mL}$ ice-cold anthrone reagents was added in all the test tubes, vortexed and placed at $100^{\circ} \mathrm{C}$ for exactly 10 min. Samples were rapidly cooled by placing the tubes into an ice bath. Absorbance was recorded for blank, standards and samples at $630 \mathrm{~nm}$ after shaking well. Total sugar contents were calculated with reference to the sugar(s) selected as standard, from the standard curve. Absorbance was recorded for blank was subtracted from samples and standards.

Statistical analysis: Data for all the treatments were subjected to analysis of variance in completely randomized design (Steel et al., 1997). The significance of differences among treatments was determined using LSD test and significant difference between means was determined according to Duncan's Multiple Range Test (Duncan, 1955).

\section{RESULTS}

Effect of PGPR and CIB on growth parameters: Axenic condition was executed in jars to study the effect of different consortium of PGPR and CIB on growth and defense response of maize crop. Different combinations of Mb4, $\mathrm{Mb} 7, \mathrm{Cb} 4$, and $\mathrm{Cb} 9$ showed the significant increase in growth parameters than other combinations of selected strains. Germination percentage is expressed by Fig.1, while data regarding root/shoot length, root/shoot weight, disease incidence and disease suppression is given in Table 1. Different combinations of above mentioned strains gave better seed germination (100\%), higher root length (up to $29.35 \mathrm{~cm}$ ), shoot length (up to $31.29 \mathrm{~cm}$ ), root weight (up to $1.59 \mathrm{~g} \mathrm{plant}^{-1}$ ) and shoot weight (up to $2.83 \mathrm{~g} \mathrm{plant}^{-1}$ ) compared to their respective control. 
Table 1. Effect of consortium of PGPR and CIB on growth of maize under axenic condition.

\begin{tabular}{|c|c|c|c|c|c|}
\hline Treatments & $\begin{array}{c}\text { Root length } \\
(\mathbf{c m})\end{array}$ & $\begin{array}{c}\text { Shoot length } \\
(\mathrm{cm})\end{array}$ & $\begin{array}{c}\text { Root weight } \\
\left(\text { g plant }^{-1}\right)\end{array}$ & $\begin{array}{c}\text { Shoot weight } \\
\left(\text { g plant }^{-1}\right)\end{array}$ & $\begin{array}{c}\text { Disease } \\
\text { incidence }(\%)\end{array}$ \\
\hline Control & $20.5 \mathrm{c} *$ & $20.33 \mathrm{~d}$ & $1.18 \mathrm{~d}$ & $1.60 \mathrm{e}$ & $88.9 \mathrm{a}$ \\
\hline $\mathrm{Mb} 4+\mathrm{Cb} 1$ & $29.04 \mathrm{a}$ & $29.32 \mathrm{ab}$ & $1.46 \mathrm{bc}$ & $2.31 \mathrm{~cd}$ & $22.2 \mathrm{~d}$ \\
\hline $\mathrm{Mb} 4_{+} \mathrm{Cb} 4$ & $29.07 \mathrm{a}$ & $31.29 \mathrm{a}$ & $1.58 \mathrm{a}$ & $2.70 \mathrm{ab}$ & $11.1 \mathrm{e}$ \\
\hline $\mathrm{Mb} 4+\mathrm{Cb} 8$ & $28.32 \mathrm{a}$ & $29.48 \mathrm{ab}$ & $1.47 \mathrm{~b}$ & $2.40 \mathrm{c}$ & $33.3 \mathrm{c}$ \\
\hline $\mathrm{Mb} 4+\mathrm{Cb} 9$ & $27.83 \mathrm{a}$ & $30.19 \mathrm{ab}$ & $1.58 \mathrm{a}$ & $2.65 \mathrm{~b}$ & $11.1 \mathrm{e}$ \\
\hline $\mathrm{Mb} 5+\mathrm{Cb} 1$ & $27.09 \mathrm{a}$ & $25.88 b c$ & $1.44 b c$ & $2.39 \mathrm{c}$ & $33.3 \mathrm{c}$ \\
\hline $\mathrm{Mb} 5+\mathrm{Cb} 4$ & $26.18 \mathrm{a}$ & $30.34 \mathrm{ab}$ & $1.45 \mathrm{bc}$ & $2.30 \mathrm{~cd}$ & $44.4 \mathrm{~b}$ \\
\hline $\mathrm{Mb} 5+\mathrm{Cb} 8$ & $28.88 \mathrm{a}$ & $26.99 \mathrm{abc}$ & $1.45 \mathrm{bc}$ & $2.41 \mathrm{c}$ & $22.2 \mathrm{~d}$ \\
\hline $\mathrm{Mb} 5+\mathrm{Cb} 9$ & $27.39 \mathrm{a}$ & $28.37 \mathrm{ab}$ & $1.41 \mathrm{c}$ & $2.32 \mathrm{~cd}$ & $22.2 \mathrm{~d}$ \\
\hline $\mathrm{Mb} 6+\mathrm{Cb} 1$ & $26.15 \mathrm{a}$ & $28.40 \mathrm{ab}$ & $1.44 \mathrm{bc}$ & $2.19 \mathrm{~d}$ & $44.4 \mathrm{~b}$ \\
\hline $\mathrm{Mb}_{+} \mathrm{Cb} 4$ & $25.25 \mathrm{ab}$ & $22.95 \mathrm{~cd}$ & $1.58 \mathrm{a}$ & $2.31 \mathrm{~cd}$ & $33.3 \mathrm{c}$ \\
\hline $\mathrm{Mb} 6+\mathrm{Cb} 8$ & $29.33 \mathrm{a}$ & $28.60 \mathrm{ab}$ & $1.46 \mathrm{bc}$ & $2.35 \mathrm{c}$ & $22.2 \mathrm{~d}$ \\
\hline $\mathrm{Mb} 6+\mathrm{Cb} 9$ & $21.07 \mathrm{bc}$ & $26.34 \mathrm{abc}$ & $1.45 \mathrm{bc}$ & $2.33 \mathrm{~cd}$ & $33.3 \mathrm{c}$ \\
\hline $\mathrm{Mb} 7+\mathrm{Cb} 1$ & $28.22 \mathrm{a}$ & $29.38 \mathrm{ab}$ & $1.47 \mathrm{~b}$ & $2.37 \mathrm{c}$ & $22.2 \mathrm{~d}$ \\
\hline $\mathrm{Mb} 7+\mathrm{Cb} 4$ & $29.21 \mathrm{a}$ & $30.23 \mathrm{ab}$ & $1.58 \mathrm{a}$ & $2.75 \mathrm{ab}$ & $11.1 \mathrm{e}$ \\
\hline $\mathrm{Mb} 7+\mathrm{Cb} 8$ & $27.41 \mathrm{a}$ & $29.26 \mathrm{ab}$ & $1.45 \mathrm{bc}$ & $2.29 \mathrm{~cd}$ & $22.2 \mathrm{~d}$ \\
\hline $\mathrm{Mb} 7+\mathrm{Cb} 9$ & $29.35 \mathrm{a}$ & $30.34 \mathrm{a}$ & $1.59 \mathrm{a}$ & $2.83 \mathrm{a}$ & $11.1 \mathrm{e}$ \\
\hline LSD & 2.296 & 4.66 & 0.059 & 0.145 & 5.236 \\
\hline
\end{tabular}

*Means sharing same letter(s) in a column do not differ significantly at $\mathrm{p}<0.05$. Data is the average of three repeats

Disease incidence was calculated after counting the diseased plants out of total plants in each treatment (Table 1). Control exhibited $88.9 \%$ disease incidence while range of disease incidence in inoculated treatments varied from 11.1 to 44.4\%. These consortiums also suppress disease up to $88.9 \%$. Least control of disease among inoculated treatments was with $\mathrm{Mb} 5+\mathrm{Cb} 1$ and $\mathrm{Mb} 6+\mathrm{Cb} 1(55.6 \%)$ but higher than control $(11.1 \%)$.
Effect of PGPR and CIB on physicochemical changes in plant: Data regarding membrane permeability, chlorophyll and relative water contents is given in Table 2. Microbial consortia with $\mathrm{Mb} 4, \mathrm{Mb} 7, \mathrm{Cb} 4$, and $\mathrm{Cb} 9$ showed decreased trend in membrane permeability compared to control. The lowest membrane permeability was observed with $\mathrm{Mb} 4+$ $\mathrm{Cb} 9(54.18 \%)$ which was statistically at par with $\mathrm{Mb} 4+\mathrm{Cb} 4$ $(55.78 \%)$ and $\mathrm{Mb} 7+\mathrm{Cb} 4(55.78 \%)$.

Table 2. Effect of consortium of PGPR and CIB on membrane permeability, chlorophyll and relative water contents.

\begin{tabular}{|c|c|c|c|c|}
\hline Treatments & ${ }^{1} \mathbf{M P}(\%)$ & ${ }^{2} \mathrm{Chl}$ a (mg/g FW) & ${ }^{2} \mathrm{Chl} \mathrm{b}(\mathrm{mg} / \mathrm{g} \mathrm{FW})$ & ${ }^{3} \mathrm{RWC}(\%)$ \\
\hline Control & 75.91a* & $0.908 \mathrm{~m}$ & $1.099 \mathrm{p}$ & $57.49 \mathrm{~g}$ \\
\hline $\mathrm{Mb} 4+\mathrm{Cb} 1$ & $70.02 b c$ & $1.175 \mathrm{i}$ & $1.897 \mathrm{o}$ & $60.43 \mathrm{efg}$ \\
\hline $\mathrm{Mb} 4_{+} \mathrm{Cb} 4$ & $55.78 \mathrm{i}$ & $1.767 \mathrm{a}$ & $2.351 \mathrm{~d}$ & $78.23 \mathrm{a}$ \\
\hline $\mathrm{Mb} 4+\mathrm{Cb} 8$ & $64.08 \mathrm{fg}$ & $1.134 \mathrm{j}$ & $2.001 \mathrm{kl}$ & $62.01 \mathrm{c}-\mathrm{g}$ \\
\hline $\mathrm{Mb} 4+\mathrm{Cb} 9$ & $54.18 \mathrm{i}$ & $1.677 \mathrm{~b}$ & $2.499 \mathrm{~b}$ & $76.78 \mathrm{a}$ \\
\hline $\mathrm{Mb} 5+\mathrm{Cb} 1$ & $66.09 \mathrm{~cd}$ & $1.176 \mathrm{i}$ & $1.977 \mathrm{n}$ & $66.0 \mathrm{bcd}$ \\
\hline $\mathrm{Mb} 5+\mathrm{Cb} 4$ & 65.89efg & $1.277 \mathrm{f}$ & $2.005 \mathrm{k}$ & $69.85 \mathrm{~b}$ \\
\hline $\mathrm{Mb} 5+\mathrm{Cb} 8$ & $68.18 \mathrm{ef}$ & $1.286 \mathrm{e}$ & $2.114 \mathrm{i}$ & $76.45 \mathrm{a}$ \\
\hline $\mathrm{Mb} 5+\mathrm{Cb} 9$ & 65.92efg & $1.134 \mathrm{j}$ & $2.012 \mathrm{j}$ & $65.41 \mathrm{~b}-\mathrm{e}$ \\
\hline $\mathrm{Mb} 6+\mathrm{Cb} 1$ & $62.07 \mathrm{gh}$ & 1.1171 & $2.132 \mathrm{~h}$ & $67.30 b c$ \\
\hline $\mathrm{Mb} 6+\mathrm{Cb} 4$ & $72.51 \mathrm{ab}$ & $1.123 \mathrm{k}$ & $2.156 \mathrm{~g}$ & $60.58 \mathrm{~d}-\mathrm{g}$ \\
\hline $\mathrm{Mb} 6+\mathrm{Cb} 8$ & $71.55 \mathrm{ab}$ & $1.243 \mathrm{~g}$ & $2.231 \mathrm{e}$ & $58.79 \mathrm{fg}$ \\
\hline $\mathrm{Mb} 6+\mathrm{Cb} 9$ & $61.71 \mathrm{~d}$ & $1.333 \mathrm{~d}$ & $2.225 \mathrm{f}$ & $63.46 c-f$ \\
\hline $\mathrm{Mb} 7+\mathrm{Cb} 1$ & $69.20 \mathrm{e}$ & $1.432 \mathrm{c}$ & 1.9981 & $59.62 \mathrm{fg}$ \\
\hline $\mathrm{Mb} 7_{+} \mathrm{Cb} 4$ & $55.78 \mathrm{i}$ & $1.766 \mathrm{a}$ & $2.513 \mathrm{a}$ & $77.56 \mathrm{a}$ \\
\hline $\mathrm{Mb} 7+\mathrm{Cb} 8$ & $61.90 \mathrm{gh}$ & $1.222 \mathrm{~h}$ & $1.985 \mathrm{~m}$ & $60.54 \mathrm{~d}-\mathrm{g}$ \\
\hline $\mathrm{Mb} 7+\mathrm{Cb} 9$ & $58.63 \mathrm{hi}$ & $1.676 \mathrm{~b}$ & $2.480 \mathrm{c}$ & $78.56 \mathrm{a}$ \\
\hline LSD & 5.010 & 0.0049 & 0.0044 & 5.5082 \\
\hline
\end{tabular}

*Means sharing same letter(s) in a column do not differ significantly at $\mathrm{p}<0.05$. Data is the average of three repeats; ${ }^{1} \mathrm{MP}$ : membrane permeability; ${ }^{2} \mathrm{Chl}$ : chlorophyll; ${ }^{3} \mathrm{RWC}$ : Relative water contents. 
Chlorophyll contents varied considerably with inoculated treatments. Chlorophyll b was elevated in all the treatments than chlorophyll a but both the values were significantly higher than control.

Relative water contents ranged from $60.43 \%(\mathrm{Mb} 4+\mathrm{Cb} 1)$ to $78.56 \%(\mathrm{Mb} 7+\mathrm{Cb} 9)$. The higher value (78.56\%) was statistically at par with Mb4 + Cb4, Mb7 + Cb4, Mb4 + Cb9 and $\mathrm{Mb} 5+\mathrm{Cb} 8$ and higher than control (57.49\%).

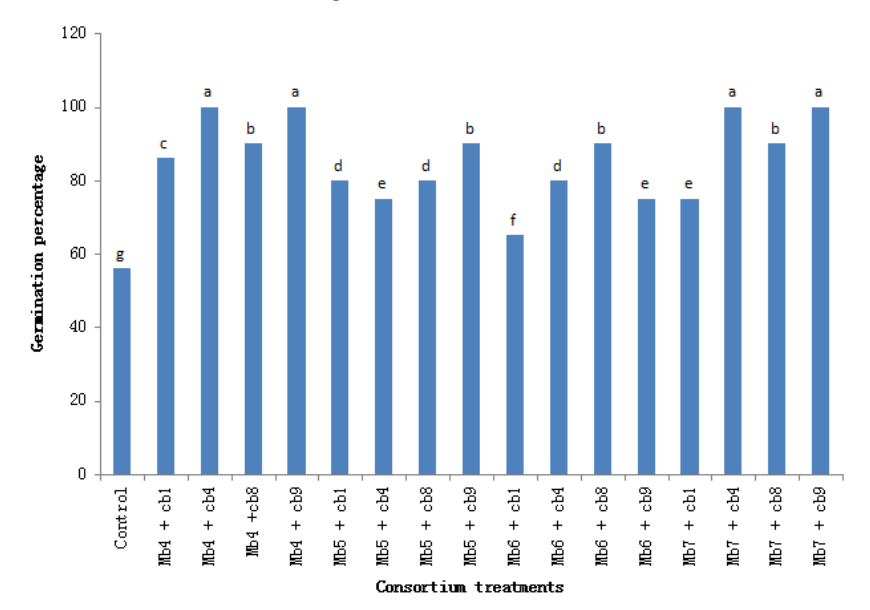

Figure 1. Effect of consortium of PGPR and CIB on seed germination of maize.

Effect of PGPR and CIB on defense compounds: Data regarding proline contents, total soluble sugar, catalase and ascorbate peroxidase activity is given in Table 3 . In response to fungal stress, proline is synthesized in various plant parts which provide relief to the stressed plant. More proline contents were observed by inoculation with different consortium of selected strains compared to control. The best consortium with respect to above mentioned enzymes were $\mathrm{Mb} 7+\mathrm{Cb} 4, \mathrm{Mb} 7+\mathrm{Cb} 9$ and Mb4 + Cb9. They showed maximum proline contents (up to $4.97 \mu \mathrm{mol} \mathrm{g} \mathrm{g}^{-1}$ ), higher catalase activity $\left(4.5 \mathrm{mM} \mathrm{H} \mathrm{H}_{2} \mathrm{~min}^{-1} \mathrm{~g}^{-1}\right)$ more ascorbate peroxidase activity $\left(0.57 \mu \mathrm{M} \mathrm{H}_{2} \mathrm{O}_{2} \mathrm{~min}^{-1} \mathrm{mg}^{-1}\right.$ protein $)$ and total soluble sugar (up to $10 \mathrm{mg} \mathrm{g}^{-1} \mathrm{FW}$ ).

\section{DISCUSSION}

Plants expose to various biotic and abiotic stresses in natural environment. To survive under such circumstances, plant has to develop a defense system in response to external signaling. Phytohormone may be the part of signaling pathways that enables plants to bear stresses. Secondary metabolites support the plant against biotic stress via signaling cross talk with requisite rhizospheric microbes. Beneficial microflora (PGPR, CIB), particularly fluorescent pseudomonads are the strong candidates to act as biocontrol agent. They produce antifungal secondary metabolites and show efficient root colonization (Erdogan and Benlioglu, 2010). They are natural enemies of the pathogens and produced antifungal metabolites at the infected site, leading to the better growth and yield of crop in diseased environment.

Efficient germination is the basic criteria for growth and yield of the crop. Seed inoculation with bacterial consortia significantly enhanced the germination of seed. Germination percentage varied with different bacterial consortia however

Table 3. Effect of consortium of PGPR and CIB on defense response of maize.

\begin{tabular}{|c|c|c|c|c|}
\hline Treatments & $\begin{array}{c}\text { Proline } \\
\mu \mathrm{mol} / \mathrm{g} \text { FW }\end{array}$ & $\begin{array}{c}\text { Catalase } \\
\mathrm{mM} \mathrm{H}_{2} \mathrm{O}_{2} / \mathrm{min} / \mathrm{g} \text { protein }\end{array}$ & $\begin{array}{c}\text { Ascorbate peroxidase } \\
\mu \mathrm{M} \mathrm{H}_{2} \mathrm{O}_{2} / \mathrm{min} / \mathrm{mg} \text { protein }\end{array}$ & $\begin{array}{c}\text { Total soluble } \\
\text { sugars mg/g Fw }\end{array}$ \\
\hline Control & $1.76 \mathrm{i}^{*}$ & $1.3 \mathrm{~d}$ & 0.251 & $5.6 \mathrm{e}$ \\
\hline $\mathrm{Mb} 4+\mathrm{Cb} 1$ & $2.19 \mathrm{gh}$ & $3.4 \mathrm{abc}$ & $0.36 \mathrm{k}$ & $6.7 \mathrm{de}$ \\
\hline $\mathrm{Mb} 4+\mathrm{Cb} 4$ & $4.14 \mathrm{~b}$ & $4.5 \mathrm{a}$ & $0.55 \mathrm{ab}$ & $9.9 \mathrm{a}$ \\
\hline $\mathrm{Mb} 4+\mathrm{Cb} 8$ & $2.11 \mathrm{~h}$ & $3.2 \mathrm{abc}$ & $0.46 \mathrm{efg}$ & $8.6 \mathrm{abc}$ \\
\hline $\mathrm{Mb} 4+\mathrm{Cb} 9$ & $4.94 \mathrm{a}$ & $4.2 \mathrm{a}$ & $0.56 \mathrm{a}$ & $10.0 \mathrm{a}$ \\
\hline $\mathrm{Mb} 5+\mathrm{Cb} 1$ & $2.14 \mathrm{~h}$ & $1.9 \mathrm{~cd}$ & $0.49 \mathrm{de}$ & $8.8 \mathrm{ab}$ \\
\hline $\mathrm{Mb} 5+\mathrm{Cb} 4$ & $3.13 \mathrm{e}$ & $2.0 \mathrm{bcd}$ & $0.44 \mathrm{fgh}$ & $7.9 \mathrm{bcd}$ \\
\hline $\mathrm{Mb} 5+\mathrm{Cb} 8$ & $2.38 \mathrm{fg}$ & $3.3 \mathrm{abc}$ & 0.50 cde & 6.9 cde \\
\hline $\mathrm{Mb} 5+\mathrm{Cb} 9$ & $3.43 \mathrm{~d}$ & $3.5 \mathrm{abc}$ & $0.47 \mathrm{def}$ & $8.8 \mathrm{ab}$ \\
\hline $\mathrm{Mb} 6+\mathrm{Cb} 1$ & $3.45 \mathrm{~d}$ & $3.9 \mathrm{a}$ & $0.43 \mathrm{f}-\mathrm{i}$ & $9.7 \mathrm{a}$ \\
\hline $\mathrm{Mb}_{+} \mathrm{Cb} 4$ & $3.48 \mathrm{~d}$ & $3.3 \mathrm{abc}$ & $0.39 \mathrm{ijk}$ & $8.7 \mathrm{ab}$ \\
\hline $\mathrm{Mb} 6+\mathrm{Cb} 8$ & $4.22 \mathrm{~b}$ & $3.6 \mathrm{ab}$ & $0.42 \mathrm{~g}-\mathrm{j}$ & 6.9 cde \\
\hline $\mathrm{Mb} 6+\mathrm{Cb} 9$ & $3.67 \mathrm{c}$ & $4.0 \mathrm{a}$ & $0.38 \mathrm{jk}$ & $9.5 \mathrm{ab}$ \\
\hline $\mathrm{Mb} 7+\mathrm{Cb} 1$ & $3.73 \mathrm{c}$ & $3.4 \mathrm{abc}$ & $0.41 \mathrm{hij}$ & $8.7 \mathrm{ab}$ \\
\hline $\mathrm{Mb} 7_{+} \mathrm{Cb} 4$ & $4.97 \mathrm{a}$ & $4.4 \mathrm{a}$ & $0.54 \mathrm{abc}$ & $9.7 \mathrm{a}$ \\
\hline $\mathrm{Mb} 7+\mathrm{Cb} 8$ & $2.54 \mathrm{f}$ & $3.8 \mathrm{a}$ & $0.51 \mathrm{bcd}$ & $5.8 \mathrm{e}$ \\
\hline $\mathrm{Mb} 7+\mathrm{Cb} 9$ & $4.79 \mathrm{a}$ & $4.1 \mathrm{a}$ & $0.57 \mathrm{a}$ & $9.6 \mathrm{ab}$ \\
\hline LSD & 0.232 & 1.610 & 0.046 & 1.800 \\
\hline
\end{tabular}

*Means sharing same letter(s) in a column do not differ significantly at $\mathrm{p}<0.05$. Data is the average of three repeats. 
all the inoculated treatments showed significantly higher germination rate than the control. It is justified by previous finding that seed treatment with antagonistic PGPR enriched the seed worth (Umesha, 2006). They have the ability to increase seed germination and plant growth, improving seedling emergence, bear the external stress and protecting plants from disease (Lugtenberg et al., 2002). Moreover, PGPR (Pseudomonas fluorescens) amplified the seed germination (Srivastava et al., 2010) and vigor of seedlings (Abo-Elyousr and El-Hendawy, 2008) by colonizing the root of cereals (maize and wheat) may be due to secretion of auxins, gibberellins and cytokinins (Rosas et al., 2009; Yao et al., 2010). Furthermore PGPR inoculation improved the seed germination in pearl millet (Niranjan et al., 2004), sunflower and wheat (Shaukat et al., 2006 a,b). It might be due to the synthesis of growth hormones which perhaps activated the specific enzymes activity, involved in prompt germination and intensification of starch assimilation.

Bacterial inoculation increased the root mass and area which help plant to absorb water and nutrients more efficiently. As a result of which plant became physically strong to tolerate biotic and abiotic stresses. In our finding root mass was higher with consortium inoculation than control. Increased biomass of root by inoculation with bacterial consortium was also observed previously by Gholami et al. (2009) and Fatima et al. (2009) in wheat. Higher biomass of root by inoculation was also recorded by Pacôme et al. (2013) in maize crop.

Our study exhibited that seed inoculation with all bacterial consortia showed an increase in plant height. Early germination and efficient absorption of water and nutrients due to well established root system leads to better growth of shoot. These results are corroborated with previous finding that plant height and leaf area was increased in different crops due to PGPR inoculation (Siddiqui and shaukat, 2002). It is attributed to capability of PGPR to promote plant growth and productivity through synthesizing phytohormone, increasing the nutrient availability, antagonizing phytopathogens and decreasing metal toxicity (Bharathi et al., 2004). Results also showed an increase in shoot dry weight in response to all inoculated treatments over control. The beneficial effect of seed inoculation with bacterial consortia on shoot dry weight and yield of maize was also reported by Shaharoona et al. (2006). Such an improvement might be due to the ability of bacteria to fix nitrogen, solubilize the phosphate and production of growth regulators (Salantur et al., 2006).

Combined application of PGPR and CIB was the most effective biocontrol strategy and provided the disease suppression against pathogen (Fusarium oxysporum). It might be due to early germination, efficient root development and competition for food and space. Root colonization is the pre requisite for pathogen to cause seedling blight in plant. CIB and PGPR are the aggressive colonizers compared to fungus thus diminished the possibility of disease initiation. Our results confirmed the previous finding that plant growth promoting rhizobacteria can be used as biofertilizer and biocontrol agents (Manikandan et al., 2010). It was also studied by Morsy et al. (2009) that the dual inoculation with Triticum viride and Bacillus subtilis was effective against Fusarium oxysporum than individual treatment. In diseased soil, beneficial bacteria help plant to promote growth by suppressing the disease through antibiosis, by inducing systemic resistance, producing toxins, bio-surfactants, lytic enzymes and competing for food and niches (Erdogan and Benlioglu, 2010). Beneficial microbes may also protect the plant against pathogens by increasing uptake of nutrient, change in the root architecture and instigation of plant defense system (Wehner et al., 2010). Antifungal activity of PGPR was particularly attributed to the production of antifungal metabolites against Fusarium oxysporum f.sp. lycopersici (Karkachi et al., 2010). The increased growth of maize crop by inoculation with bacterial consortium was probably due to the additive effect of PGPR and CIB for disease suppressive potential under diseased environment.

Membrane permeability/electrolyte leakage increased under stress. PGPR and CIB inoculation decreased it by strengthening the plant due to nutrient availability. It may be due to interaction between plant and beneficial microbes, which improved the nutrient uptake, increase resistance against soil-borne pathogens and reduce the effect of heavy metals and drought stress (Gosling et al., 2006).

Chlorophyll contents decreased due to fungal stress however significantly higher chlorophyll contents were observed by inoculation with bacterial consortia. Chloroplasts are membrane bound organelles and its constancy depends upon membrane stability. Increased membrane permeability under stressed condition did not keep them intact and results in chlorophyll reduction (Ashraf et al., 2005). Chlorophyll contents decreased due to mobilization of thylakoid proteolipids and thus decrease the photosynthesis (Thomas et al., 2000). Chlorophyll a, b and a/b significantly decreased under stress condition (Moussa, 2006; Iqbal et al., 2006).

Significant variation in relative water contents were observed due to bacterial inoculation but all the inoculated treatments had significantly higher water contents than control. Fusarium spp affected the plant by entering into the vascular tissues and blocked the uptake of water and nutrients (Agrios et al., 2005). In the defence response of citrus against Alternaria infection, increased rate of respiration was observed (Timmer et al., 2003). PGPR and CIB colonize the root and prohibited the fungus to enter the vascular tissues of the plant thus maintain relative water contents in the aerial parts of the plant.

Proline acts as antioxidant and scavenged reactive oxygen species (ROS). Proline, glycine betaine and sugars were solutes, accumulated in plant parts under stressed condition 
(Qasim et al., 2003). Proline concentration varies from 5\% under normal condition to $80 \%$ under stressed condition in many plants (Szabados and Savoure, 2009). Proline helps plant to maintain cytosolic $\mathrm{pH}$, boost up the bustle of diverse enzymes, act as molecular chaperones and regulates the intercellular redox reaction (Verbruggen and Hermans, 2008). Several plant species, inoculated with PGPR revealed high concentration of proline under stressed condition (Kohler et al. 2009; Vardharajula et al., 2011). Proline and other compatible solutes were synthesized using 41 moles of ATP but help plant to survive and recover under stressed condition (Munns and Tester, 2008).

Catalase and ascorbate peroxidase activity increased, by coinoculation with bacterial consortia. Under stressed condition concentration of $\mathrm{H}_{2} \mathrm{O}_{2}$ increased in the plant leaves and root. Catalase act as sink for $\mathrm{H}_{2} \mathrm{O}_{2}$ and help plant to survive under stressed condition. $\mathrm{H}_{2} \mathrm{O}_{2}$ is a toxic agent and act as signaling molecule to regulate the expression of genes related to antioxidants and defense proteins in cells (Hung et al., 2005). The stressed condition of plant is associated with up or down regulation of hundreds of defense related genes (Cheeseman, 2007). Defense proteins, such as peroxidase (POX) are induced in response to pathogen invasion in different plants (Ramamoorthy et al., 2002). The increased activity of peroxidase is a valuable indicator for localized and systemic acquired resistance in diseased plants (ElKhallal, 2007). Systemic resistance is induced by PGPR against Fusarium oxysporum due to the accumulation of peroxidase and other defense related proteins in banana (Thangavelu et al., 2003; Saravanan et al., 2004). Cellular compartments including chloroplast were high in antioxidants such as ascorbic acid and glutathione and provide defense against oxidative stress (Miller et al., 2010). Increase in soluble sugar contents was observed in diseased plants. It is justified by the fact that plant stopped assimilatory metabolism (photosynthesis) when started respiration and other functions, necessary for defense (Berger et al., 2007). Degradation of starch in diseased parts of the plant resulted in starch depletion and higher sugar contents (Patakas and Noitsak, 2001), thus increased the soluble sugars: starch ratio. The tolerance mechanism in stressed plant may be linked to accumulation of osmoprotectants such as soluble sugars. Accumulation of soluble sugars was related to water deficit in plants (Hoekstra and Buitink, 2001). Fusarium attack blocked the vascular bundles of immature stems due to mycelium growth and results in wilting (Agrios et al., 2005). Phytopathogens secreted carbohydrate results in an increase of monosaccharide and decrease of disaccharide contents in diseased leaves (Qin et al., 2007; Abdalla and El-Khoshiban, 2007). Escalation in the soluble and reducing sugar was observed in diseased plants by Ijaz et al. (2011) and Chung (2012). Consortium of compatible bacterial isolates help plant to grow successfully in biotic stress by inducing physicochemical changes and producing defense compounds in stressed plant

Conclusion: Under stressed condition, synergistic plantbacterial association plays a vital role in supporting the plant growth and health. Some species of Fusarium cause seedling blight in maize crop. In order to provide maximum benefit to the crop, efficient root colonization by beneficial bacteria is of paramount importance. They also protect the plant from pathogens by triggering the production of defense compounds in the plant. It is suggested that inoculation of maize with the consortium of selected isolates of PGPR and CIB having above mentioned characteristics, act as effective biocontrol agent against Fusarium oxysporum. Different consortium of PGPR and CIB isolates for disease suppression via production of defense hormone and growth promotion is a good device to select compatible isolates of PGPR and CIB in biocontrol technology. Accumulation of defense enzymes such as proline, catalase, ascorbate peroxidase and total soluble sugars induced resistance in plant against Fusarium oxysporum.

\section{REFERENCES}

Abdalla, M.M. and N.H. El-Khoshiban. 2007. The influence of water stress on growth, relative water content, photosynthetic pigments, some metabolic and hormonal contents of two Triticium aestivum cultivars. J. Appl. Sci. Res. 3: 2062-2074.

Abo-Elyousr, K.A.M. and H.H. El-Hendawy. 2008. Integration of Pseudomonas fluorescens and acibenzolar-S-methyl to control bacterial spot disease of tomato. Crop Prot. 27: 1118-1124.

Aebi, H. 1984. Catalase in vitro Meth. Enzymol. 105: 121126.

Agrios, G.N. 2005. Plant Pathology, $5^{\text {th }}$ Ed. Elsevier Academic Press, Amsterdam.

Arnon, D.I. 1949. Cooper enzymes in isolated chloroplasts. Polyphenol-oxidase in veta vulgaris. Plant Physiol. 24: $1-15$.

Arora, N.K., S.C. Kang and D.K. Maheshwari. 2001. Isolation of siderophore-producing strains of Rhizobium meliloti and their biocontrol potential against Macrophomina phaseolina that causes charcoal rot of groundnut. Curr. Sci. 8: 673-677.

Ashraf, $M$ and M.R. Foolad. 2005. Pre-sowing seed treatment-a shotgun approach to improve germination, plant growth and crop yield under saline and non-saline conditions. Adv. Agron. 88: 223-271.

Barnett, H.L. and B.B. Hunter. 1975. Illustrated Genera of Imperfect Fungi. Minneapolis, MN, USA, Burgess, pp.1-218. 
Bates, L.S., R.P. Waldren and I.D. Teare. 1973. Rapid determination of free proline in water-stress studies. Plant Soil 39: 205-207.

Berger, S., A.K. Sinha and T. Roitsch. 2007. Plant physiology meets phytopathology: plant primary metabolism and plant pathogen Interactions. J. Exp. Bot. 58: 4019-4026.

Bharathi, R., R. Vivekananthan, S. Harish, A. Ramanathan and R. Samiyappan. 2004. Rhizobacteria-based bioformulations for the management of fruit rot infection in chillies. Crop Prot. 23: 835-843.

Boller, T. and G. Felix. 2009. A renaissance of elicitors: perception of microbe-associated molecular patterns and danger signals by pattern recognition receptors. Ann. Rev. Plant Biol. 60: 379-406.

Browse, J. 2009. Jasmonate passes muster: a receptor and targets for the defense hormone. Ann. Rev. Plant Biol. 60: 183-205.

Carisse, O., J. Bernier and N. Benhamou. 2003. Selection of biological agents from composts for control of damping-off of cucumber caused by Pythium ultimum. Plant Pathol. 25: 258-267.

Charles, W.B. and D.M. Hinton. 2007. Potential for control of seedling blight of wheat caused by Fusarium graminearum and related species using the bacterial endophyte Bacillus mojavensis. Biocontrol Sci. Technol. 17: 81-94.

Cheeseman, J.M. 2007. Hydrogen peroxide and plant stress: A challenging relationship. Plant Stress 1: 4-15.

Chung, K.R. 2012. Stress response and pathogenicity of the necrotrophic fungal pathogen Alternaria alternata. Scientifica 2012: 1-17.

Compant, S., B. Duffy, J. Nowak, C. Clement and E.A. Barka. 2005. Use of plant growth promoting bacteria for biocontrol of plant disease: Principles, mechanisms of action and future prospects. Applied Environ. Microbiol. 71: 4951-4959.

Deshwal, V.K., R.C. Dubey and D.K. Maheshwari. 2003. Isolation of plant growth promoting strains of Brady Rhizobium sp. (Arachis) with biocontrol potential against Macrophomina phaseolina causing charcol rot of peanut. Curr. Sci. 84: 443-444.

Duncan, D.B. 1955. Multiple Range and Multiple F-Test. Biometrics 11: 1-42.

El-Khallal, M.S. 2007. Induction and modulation of resistance in tomato plants against Fusarium wilt disease by bioagent fungi (Arbuscular mycorrhiza) and/or hormonal elicitors (Jasmonic Acid \& Salicylic Acid): 2- Changes in the antioxidant enzymes, phenolic compounds and pathogen related- proteins. Aust. J. Basic Appl. Sci. 1: 717-732.

Erdogan, O. and K. Benlioglu. 2010. Biological control of Verticillium wilts on cotton by the use of fluorescent
Pseudomonas spp. under field conditions. Biol. Control 53: 39-45.

Fatima, Z., M. Saleemi, M. Zia, T. Sultan, M. Aslam, R. Rehman and M.F. Chaudhary. 2009. Antifungal activity of plant growth-promoting rhizobacteria isolates against Rhizoctonia solani in wheat. Afr. J. Biotechnol. 8: 219225 .

Garcia-Brugger, A., O. Lamotte, E. Vandelle, S. Bourque, D. Lecourieux, B. Poinssot, D. Wendehenne and A. Pugin. 2006. Early signaling events induced by elicitors of plant defenses. Molecular Plant-Microbe Interact. 19: 711-724.

Gholami, A., S. Shahsavani and S. Nezarat. 2009. The effect of plant growth promoting rhizobacteria (PGPR) on germination, seedling growth and yield of maize. World Acad. Sci. Engin.Technol. 49: 19-24.

Gosling, P., A. Hodge, G. Goodlass and G.D. Bending. 2006. Arbuscular mycorrhizal fungi and organic farming. Agric. Ecosyst. Environ. 113: 17-35.

Heath, M.C. 2000. Hypersensitive response related death. Plant Mol. Biol. 44: 321-334.

Hoagland, D.R. and D. Arnon. 1950. The water culture methods for growing plants without soil. Calif. Agri. Exp. Sta. Circ. 347: 39.

Hoekstra, F.A. and J. Buitink. 2001. Mechanisms of plant desiccation tolerance. Trends Plant Sci. 8: 431-438.

Hung, S., C. Yu and C.H. Lin. 2005. Hydrogen peroxide functions as a stress signal in plants. Bot. Bull. Acad. Sinica. 46: 1-10.

Ijaz, A, Z. Anwar, Y. Zafar, I. Hussain, A. Muhammad, M. Irshad and S. Mehmood. 2011. Optimization of cellulose enzyme production from corn cobs using Alternaria alternata by solid state fermentation. J. Cell Mol. Biol. 9: 51-56.

Iqbal, N., M.Y. Ashraf, J. Farrukh, M. Vicente and A. Kafeel. 2006. Nitrate reduction and nutrient accumulation in wheat (Triticum aestivum L.) grown in soil salinization with four different salts. J. Plant Nutr. 29: 409-421.

Jos, M.R., T.C. Paulitz, C. Steinberg S. Christian, C. Alabouvette and Y. Moenne-Loccoz. 2009. The Rhizosphere: A playground and battlefield for soil borne pathogens and beneficial microorganisms. Plant Soil 321: 341-361.

Karkachi, N.E., S. Gharbi, M. Kihal, J.E. Henni. 2010. Biological control of Fusarium oxysporum f.sp. lycopersici isolated from Algerian tomato by Pseudomonas fluorescens, Bacillus cereus, Serratia marcescens and Trichoderma harzianum. Res. J. Agron. 4: 31-34.

Kohler, J., J.A. Hernandez, F. Caravaca, A. Roldan. 2009. Induction of antioxidant enzymes is involved in the greater effectiveness of a PGPR versus AM fungi with 


\section{Effect of consortium on physicochemical changes and defense of maize}

respect to increasing the tolerance of lettuce to severe salt stress. Environ. Exp. Bot. 65: 245-252.

Lugtenberg, B., T. Chin-A-Woeng and G. Bloemberg. 2002. Microbe-Plant Interactions: Principles and mechanisms. Antonie van Leeuwenhoek 81: 373-383.

Luria, S.E. and J.W. Burrous. 1995. Hybridization between Escherichia coli and Shigella. J. Bacteriol. 74: 461-476.

Manikandan, R., D. Saravanakumar, L. Rajendran, T. Raguchander and R. Samiyappan. 2010 Standardization of liquid formulation of Pseudomonas fluorescens Pf1 for its efficacy against Fusarium wilt of tomato. Biol. Control 54: 83-89.

Mayak, S., T. Tirosh and B.R. Glick. 2004. Plant growthpromoting bacteria confer resistance in tomato plants to salt stress. Plant Physiol. Biochem. 42: 565-572.

Meloni, D.A., M.A. Oliva, H.A. Ruiz and C.A. Martinez. 2001. Contribution of proline and inorganic solutes to osmotic adjustment in cotton under salt stress. J. Plant Nutr. 24: 599-612.

Miller, G., N. Susuki, S. Ciftci-Yilmaz and R. Mittler. 2010. Reactive oxygen species homeostasis and signalling during drought and salinity stresses. Plant Cell Environ. 33: 453-467.

Morris, D.L. 1948. Quantitative determination of carbohydrates with Drywood's anthrone reagent. Sci. 107:254-255.

Morsy, S.M., K.A. Abdel-Kawi and M.N.A. Khalil. 2009. Efficiency of Trichoderma viride and Bacillus subtilis as biocontrol agents against Fusarium solani on tomato plants. Egypt. J. Phytopathol. 38: 47-57.

Moussa, R.H. 2006. Influence of exogenous application of silicon on physiological response of salt-stressed maize (Zea mays L.). Int. J. Agric. Biol. 8: 293-297.

Munns, R. and M. Tester. 2008. Mechanisms of salinity tolerance. Ann. Rev. Plant Biol. 59: 651-681.

Nakano, Y. and K. Asada. 1981. Hydrogen peroxide is scavenged by ascorbate-specific peroxidase in spinach chloroplasts, Plant Cell Physiol. 22: 867-880.

Niranjan, S.R., N.P. Shetty and H.S. Shetty. 2004. Seed biopriming with Pseudomonas fluorescens isolates enhances growth of pearl millet plants and induces resistance against downy mildew. J. Pest Manage. 50: 41-48.

Noble, R. and E. Coventry. 2005. Suppression of soil-borne plant diseases with composts: a review. Biocontr. Sci. Technol. 15: 3-20.

Noumavo, P.A., E. Kochoni, Y.O. Didagbe, A. Adjanohoun, M. Allagbe, R. Sikirou, E.W. Gachomo, S.O. Kotchoni and L. Baba-Moussa. 2013. Effect of different plant growth promoting rhizobacteria on maize seed germination and seedling development. Amer. J. Plant Sci. 4: 1013-1021.
Patakas, A. and B. Noitsakis. 2001. Leaf age effects on solute accumulation in water-stressed grapevines. Plant physiol. 158: 63-69.

Pozo, M.J., C. Cordier, E. Dumas-Gaudot, S. Gianinazzi, J.M. Barea and G. Azcon-Aguilar. 2002. Localized versus systemic effect of arbuscular mycorrhizal fungi on defense responses to Phytophthora infection in tomato plant. J. Exp. Bot. 53: 525-534.

Prado, F.E., C. Boero, M. Gallardo and J.A. Gonzalez. 2000. Effect of $\mathrm{NaCl}$ on germination, growth, and soluble sugar content in Chenopodium quinoa Willd. seeds. Bot. Bull. Acad. Sinica 41: 27-34.

Pugliese, M., B.P. Liu, M.L. Gullino and A. Garibaldi. 2008. Selection of antagonists from compost to control soil borne pathogens. J. Plant Dis. Plant Protect. 115: 220228.

Qasim, M., M. Ashraf, M.A. Jamil, M.Y. Ashraf and E.S.R. Shafiq-ur-Rehman. 2003. Water relations and leaf gas exchange properties in some elite canola (Brassica napus) lines under salt stress. Ann. Appl. Biol. 142: 307-316.

Qin, G., S. Tian, Z. Chan and B. Li. 2007. Crucial role of antioxidant proteins and hydrolytic enzymes in pathogenicity of Penicillium expansum. Mol. Cell Proteomics 6: 425-438.

Ramamoorthy, V., T. Raguchander and R. Samiyappan. 2002. Induction of defense-related proteins in tomato roots treated with Pseudomonas fluorescens Pf1 and Fusarium oxysporum f. sp. Lycopersici. Plant Soil 239: 55-68.

Rangaswami, G. 1958. An agar blocks technique for isolating soil micro organisms with special reference to pythiaceous fungi. Sci. Cult. 24: 85.

Reuveni, R., M. Raviv, A. Krasnovsky, L. Freiman, S. Medina, A. Bar and D. Orion. 2002. Compost induces protection against Fusarium oxysporum in sweet basil. Crop Prot. 21: 583-587.

Rosas, S.B., G. Avanzini, E. Carlier, C. Pasluosta, N. Pastor and M. Rovera. 2009. Root colonization and growth promotion of wheat and maize by Pseudomonas aurantiaca SR1. Soil Biol. Biochem. 41: 1802-1806.

Salantur, A., A. Ozturk and S. Akten. 2006. Growth and yield response of spring wheat (Triticum aestivum L.) to inoculation with rhizobacteria. Plant Soil Environ. 52: 111-118.

Saravanan, R.S. and J.K.C. Rose. 2004. A critical evaluation of sample extraction techniques for enhanced proteomic analysis of recalcitrant plant tissues. Proteomics 4: 2522-2532.

Sekar, S. and D. Kandavel. 2010. Interaction of plant growth promoting rhizobacteria (PGPR) and endophytes with medicinal plants new avenues for phytochemicals. J. Phytol. 2: 91-100. 
Shaharoona, B., M. Arshad, Z.A. Zahir and A. Khalid. 2006. Performance of Pseudomonas spp. containing ACCdeaminase for improving growth and yield of maize (Zea mays L.) in the presence of nitrogenous fertilizer. Soil Biol. Biochem. 38: 2971-2975.

Shaukat, K., S. Affrasayab and S. Hasnain. 2006a. Growth responses of Triticum aestivum to plant growth promoting rhizobacteria used as a biofertilizer. Res. J. Microbiol. 1: 330-338.

Shaukat, K., S. Affrasayab and S. Hasnain. 2006b. Growth responses of Helianthus annus to plant growth promoting rhizobacteria used as a biofertilizer. J Agric. Res. 1: 573-581.

Siddiqui, I.A. and S.S. Shaukat. 2002. Mixtures of plant disease suppressive bacteria enhance biological control of multiple tomato pathogens. Biol. Fertil. Soil 36: 260268.

Singh, K., J.C. Frisvad, U. Thrane and S.B. Mathur. 1991. An illustrated manual on identification of some seedborne Aspergilli, Fusaria, Penicillia and their mycotoxins. Danish Government Institute of Seed Pathology, Copenhagen, Denmark.

Srivastava, R., A. Khalid, U.S. Singh and A.K. Sharma. 2010. Evaluation of arbuscular mycorrhizal fungus, Pseudomonas fluorescent and Terichoderma harzianum formulation against Fusarium oxysporum f. sp. lycopersici for the management of tomato wilt. Biol. Control 53: 24-31.

Steel, R.G.D., J.H. Torrie and D.A. Dicky. 1997. Principles and Procedures of Statistics- A Biometrical Approach, $3^{\text {rd }}$ Ed. McGraw-Hill Book International Co., Singapore.

Szabados, L. and A. Savoure. 2009. Proline: a multifunctional amino acid. Trends in Plant Sci. 15: 8997.

Termorshuizen, A.J., E. van Rijn, D.J. van der Gaag, C. Alabouvette, Y. Chen, J. Lagerlof, A.A. Malandrakis, E.J. Paplomatas, B. Ramert, J. Ryckeboer, C. Steinberg and S. Zmora-Nahum. 2006. Suppressiveness of 18 composts against 7 soil borne plant pathogens. Soil Biol. Biochem. 38: 2461-2477.

Thangavelu, R., A. Palaniswami, S. Doraiswamy and R. Vvelazhahan. 2003. The effect of Pseudomonas fluorescens and Fusarium oxysporum f. sp. Cubense on induction of defense enzymes and phenolics in banana. Biol. Plant. 46: 107-112.

Thomas, H. and C.J. Howarth. 2000. Five ways to stay green. J. Exp. Bot. 51: 329-337.

Timmer, L.W., T.L. Peever, Z. Solel and K. Akimitsu. 2003. Alternaria diseases of citrus-Novel pathosystems. Phytopathol. Mediterr. 42: 99-112.

Umesha, S. 2006. Occurrence of bacterial canker in tomato field of Karnataka and effect of biological seed treatment on disease incidence. Crop Prot. 25: 375-381.

Vardharajula, S., S.Z. Ali, M. Grover, G. Reddy and V. Bandi. 2011. Drought tolerant plant growth promoting Bacillus spp.: effect on growth, osmolytes, and antioxidant status of maize under drought stress. J. Plant Interact. 6: 1-14.

Verbruggen, N. and C. Hermans. 2008. Proline accumulation in plants: a review. Amino Acids 35: 753759.

Vincent, J.M. 1947. Distortion of fungal hyphae in the presence of certain inhibitors. Nature 150: 850-853.

Vivas, A., A. Marulanda, J.M. Ruiz-Lozano, J.M. Barea and R. Azcon. 2003. Influence of a Bacillus sp. on physiological activities of two arbuscular mycorrhizal fungi and on plant responses to PEG induced drought stress. Mycorrhiza 13: 249-256.

Vlot, A.C., D.A. Dempsey and D.F. Klessig. 2009. Salicylic acid, a multifaceted hormone to combat disease. Ann. Rev. Phytopathol. 47: 177-206.

Wehner, J., P.M. Antunes, J.R. Powell, J. Mazukatow and M.C. Rillig. 2010. Plant pathogen protection by arbuscular mycorrhizas: A role for fungal diversity. Pedobiologia 53: 197-201.

Whetherley, P.E. 1950. Studies in the water relations of cotton plants. The field measurement of water deficit in leaves. New Phytol. 49: 81-87.

Yang, Y.O. and D.F. Klessig. 1996. Isolation and characterization of a tobacco mosaic virus-inducible myb oncogene homolog from tobacco. Proc. Nat. Acad. Sci. USA 93: 14972-14977.

Yao, L., Z. Wu, Y. Zheng, I. Kaleem and C. Li. 2010. Growth promotion and protection against salt stress by Pseudomonas putida Rs-198 on cotton. Eur. J. Soil Biol. 46: 49-54. 